\title{
Additions of two red algae to marine macro algal flora of Kerala Coast, India
}

\author{
S. K. Yadav, M. Palanisamy ${ }^{凶}$ and G. V. S. Murthy \\ Botanical Survey of India, Southern Regional Centre, Coimbatore - 641 003, Tamil Nadu, India \\ 凶Corresponding author: samy_bsi@yahoo.co.in
}

\section{भारत में केरल तट के समुद्रीय दीर्घ शैवाल वनस्पतिजात में दो लाल शैवालों का संयोजन}

एस. के. यादव, एम. पलानीसामी एवं जी. वी. एस. मूर्ति

\section{सारांश}

वर्ष 2011-2014 में केरल तट पर किये गये व्यापक समन्वेषणों के फलस्वरूप दो लाल शैवालों (रोडोफायसी) हैलोपेल्टिस ऑस्ट्रेलिस (जे. अगर्ध.) जी. डब्ल्यू. सोन्डर्स (रोडोमिनिऐसी) एवं डाऐसिया फ्लेजिलिफेरा बोरगेसन (डायेसिऐसी) के नवीन वितरणपरक अभिलेख प्राप्त किये गये हैं। प्रस्तुत शोध पत्र में इन दोनों जातियों के सही उद्धरण के साथ प्रगणित कर, संक्षेप वर्णन, प्राप्ति एवं संबद्ध जातियों पर टिप्पण दिया गया है।

\section{ABSTRACT}

Comprehensive explorations conducted in Kerala coast during 2011-2014 revealed new distributional record of two Red algae (Rhodophyceae) namely Halopeltis australis (J. Agardh) G.W. Saunders (Rhodymeniaceae) and Dasya flagellifera Boergesen (Dasyaceae). Both taxa are enumerated here with the correct citation, a short description, notes on its occurence and associated species.

Keywords: Additions, Flora, Kerala Coast, Marine Macro Algae, Rhodophyceae

\section{INTRODUCTION}

The state of Kerala, with its $580 \mathrm{~km}$ long coastline remarkably endowed with significant natural rocky landscapes which play an important role in supporting seaweed vegetation. A perusal of literature reveals that many sporadic explorations has been undertaken to assess the seaweed resources (Nair \& al., 1982; Chennubhotla \& al., 1990; Mathew, 1991; Panikkar \& Ampili, 1993; Anilkumar \& Panikkar, 1992, 1994, 1997; Kaliaperumal \& Chennubhotla, 1997; Anilkumar,
2003; Kaladharan, 2005; Sulekha \& Panikkar, 2006; Nettar and Panikkar, 2009). During the present study, 56 species of Red seaweeds are reported from Kerala coast. However, two taxa i.e. Halopeltis australis (J. Agardh) G.W. Saunders (Rhodymeniaceae) and Dasya flagellifera Boergesen (Dasyaceae) that are collected for the first time from Kerala coast, thus can be treated as new. Both taxa are enumerated here with the correct citation, a short description, notes on its occurence and associated species. 


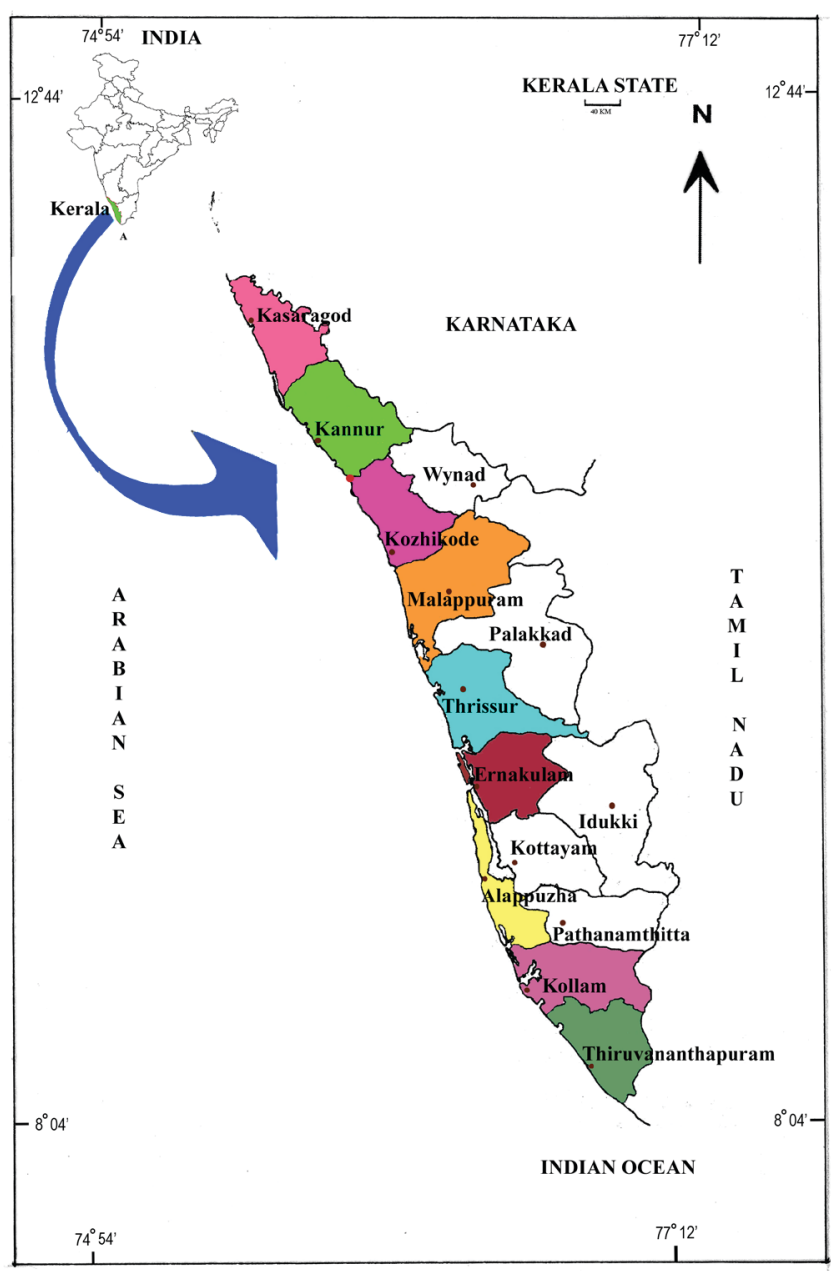

Fig. 1: Map showing Kerala coast

\section{TAXONOMIC TREATMENT}

Halopeltis J. Agardh

Halopeltis australis (J. Agardh) G.W. Saunders in G.W. Saunders \& B. McDonald, Botany 88: 657, figs. 77. 2010. Acropeltis australis J. Agardh Bot. Zeit. 3: 56. 1845. Rhodymenia australis Sond., Bot. Zeit. 3:56. 1845 (nom. illeg.); K. S. Sriniv., Phycol. Ind.: 1: 22, Pl. 22. 1969; Desikachary \& al., Rhodophyta 2 (2B): 167. 1998. Rhodymenia sonderi P.C. Silva, Cat. Benth. Mar. Alg. Ind. Ocean: 370. 1996; Kalimuthu, Stud. Indian Rhodym. 23. 2000; Oza \& Zaidi, Rev. Checkl. Ind. Mar. Alg.: 63. 2001; Jha \& al., Seaweeds Gujarat: 187. 2009; P.S.N. Rao \& Gupta, Algae India 3: 52. 2015.

(Plate 1a-d)

Thallus dark-purple red in colour, frondose, up to 15 cm long, bushy, erect, epilithic. Holdfast small, discoid, firmly attached. Stipe cylindrical or stalked to slightly flat, $0.5-2 \mathrm{~mm}$ long and $180-560 \mu \mathrm{m}$ wide. Fronds almost uniformly flattened, up to $3 \mathrm{~mm}$ wide, usually dichotomously branched, angles between branches usually acute, cartilaginous; surface smooth; margins usually entire, occasionally irregularly proliferated in apical region, proliferations up to $1 \mathrm{~cm}$ long; apex usually obtuse.

Microscopic: Cells in surface view spherical to oval, 1.80$4.75 \mu \mathrm{m}$ across, thin walled, sparsely arranged. In cross section, thallus up to $435 \mu \mathrm{m}$ thick, differentiated into outer cortex and central medullary layers; cortex multi-layered, up to $95 \mu \mathrm{m}$ thick, cells oval to spherical, 6-18 $\mu \mathrm{m}$ across, compact; medulla multi-layered, up to $200 \mu \mathrm{m}$ thick, cells spherical to oval or slightly elongate, 20-58 $\mu \mathrm{m}$ across, progressively smaller towards periphery, thin walled. Spermatangia scattered over the surface; carposporangia develop in chains; cystocarps protruding or scattered on frond surface, usually hemispherical, slightly constricted at base, up to $500 \mu \mathrm{m}$ across; tetrasporangia develop in nemathecial sori, mostly concentrated below frond apices, usually subspherical, cruciately divided.

Occurrence: Post-monsoon season. Rare.

Distribution: KERALA: Kozhikode and Thiruvananthapuram districts. INDIA: Andaman Islands, Goa, Gujarat, Karnataka, Maharashtra and Tamil Nadu.

Notes: In most of the literature, this species has been treated as Rhodymenia sonderi P.C. Silva. However, recently Saunder \& McDonald (2010), based on the molecular study and DNA barcoding placed this taxon under the genus Halopeltis and named as $H$. australis.

This species usually found in association with Bryopsis plumosa, Champia compressa, Dictyota dichotoma, Gracilaria corticata and Hypnea musciformis in narrow crevices of rocks or in rock pools under heavy surf-exposed areas in intertidal region. During the field surveys, this species was collected only once from the Thikkodi coast (Plate 1 a).

Specimens examined: KERALA: Kozhikode Distr.: Thikkodi (near light house area), 08.10.2013, M. Palanisamy \& S. K. Yadav $129484(\mathrm{MH})$.

Dasya C. Agardh

Dasya flagellifera Boergesen, Biol. Meddel. Kongel Danske Vidensk.Selsk. 11(6): 50, f. 7,8. pl. 1.1934; K.S. Sriniv. in Bull. Bot. Surv. India 7: 248. 1965; P.C. Silva \& al., Cat. Benth. Mar. Alg. Ind. Ocean: 436. 1996; Desikachary \& al., Rhodophyta 2 (2B): 278. 1998; Oza \& Zaidi, Rev. Checkl. Ind. Mar. Alg.: 75. 2001; P.S.N. Rao \& Gupta, Algae India 3: 57. 2015.

(Plate 1 e-f) 


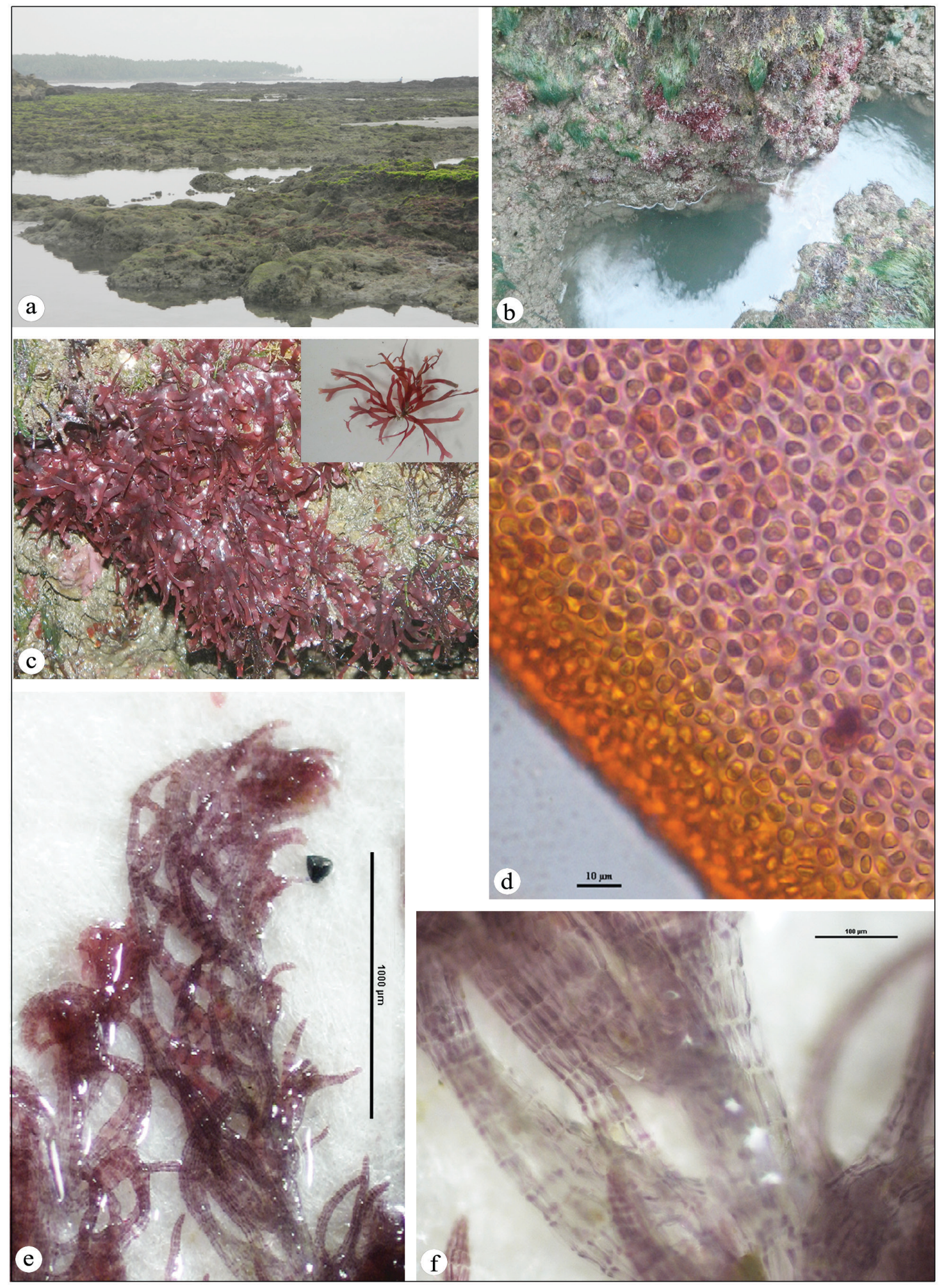

Plate -1: a. View of Thikkodi coast during low tide; b-d. Halopeltis australis (J. Agardh) G.W. Saunders: b. Habitat; c. Habit and closeup of thallus; d. Microscopic image showing surface cells of thallus $(40 \times)$; e-f. Dasya flagellifera Boergesen: e. Microscopic image showing upper part of a young thallus (Herbarium specimen); f. Microscopic images showing profuse branching in upper part of frond (10x). 
Thallus dark to purple or pinkish red in colour and turns black after drying, filamentous, up to $10 \mathrm{~cm}$ long, sympodial, corticated, bushy, tufted, gregarious, densely and irregularly branched, erect, usually epilithic. Holdfast minute, inconspicuous, rhizoidal or discoid, firmly attached on rocky substrata in intertidal regions. Stipe filamentous, variable in length. Frond filamentous, profusely and irregularly branched with pseudolaterals; pseudolaterlas flagella like, $180-600 \times 15-45 \mu \mathrm{m}$, slightly curved upwards, fastigiate, deciduous in older parts and dense and crowded in younger parts of the thallus, polysiphonous towards base and gradually tapering and become monosiphonous towards apex.

Microscopic: Axial cell with 5 pericentral cells. Tetrasporangia develop in stichidia on branches of pseudolaterals; stichidia ovate to oblong and gradually become subcylindrical, tetrahedrally developed.

Occurrence: Summer season. Rare.

Distribution: KERALA: Thiruvananthapuram. INDIA: Gujarat, Maharashtra and Tamil Nadu. Endemic to Indian coast (Oza \& Zaidi, 2001).

Note: This species was originally reported by Boergesen (1934) from Okha port of Gujarat coast, India. The specimen collected here from Kerala (Vizhinjam coast) was in very young stage and found growing in association with Gelidium micropterum near the fresh water inlet into sea.

Specimens examined: Thiruvananthapuram Distr.: Vizhinjam coast, 13.06.2013, M. Palanisamy \& S. K. Yadav $128556(\mathrm{MH})$.

\section{ACKNOWLEDGEMENT}

The authors are thankful to Dr. Paramjit Singh, Director, Botanical Survey of India, Kolkata for the facilities.

\section{REFERENCES}

ANILKUMAR, C. 2003. Species of Ceramium (Cermiales Rhodophyta) from Kerala. Bull. Bot. Surv. India 45 (1-4): 173-178.

ANILKUMAR, C. AND M.V.N. PANIKKAR 1992. Marine algae of Kerala - II: Sphacelaria Lyngbye (Sphacelariales, Phaeophyceae). Seaweed Res. Utiln. 15 (1\&2): 129-134.

ANILKUMAR, C. AND M.V.N.PANIKKAR 1994. Species of Polysiphonia Greville (Ceramiales, Rhodophyta) from the Kerala coast, India. Bionature14: 53-55.
ANILKUMAR,C. AND M.V.N. PANIKKAR 1997. Indian species of Porphyra (Rhodophyceae, Bangiales).Feddes Repert. 108 (5\&6): 419-423.

ANILKUMAR, C., P. SINDHU AND M.V.N. PANIKKAR 1995. Ecology and reproductive Phenology of Porphyra suborbiculata Kjellman (Bangiales, Rhodophyceae) from Kerala. Seaweed Res. Ultin. 17 (1\&2): 37-50.

CHENNUBHOTLA, V.S.K., S. MATHEW AND I. JOSEPH 1990. A note on the occurrence of Porphyra kanyakumariensis (Bangiales: Rhodophyta) along the Kerala coast. Seaweed Res. Utiln.13 (1): 1-4.

DESIKACHARY, T.V., V. KRISHNAMURTHY AND M.S. BALAKRISHNAN 1998. Rhodophyta Vol. II. Part-II B. Madras Science Foundation, Chennai. pp.359.

GUIRY, M.D. AND G.M. GUIRY 2016.Algae Base.World-wide electronic publication, National University of Ireland, Galway. (http: //www.algaebase.org.).

JHA, B., C.R.K. REDDY, M.K. THAKUR AND M.U. RAO 2009. Seaweeds of India: The Diversity and Distribution of Seaweeds in Gujarat Coast. CSMCRI, Bhavnagar. pp. 215

KALADHARAN, P. 2005. Gracilariopsis lemaneiformis (Bory) Dawson - a red alga reported from certain backwaters of Kerala. J. Bombay Nat. Hist. Soc.102 (3): 378.

KALIAPERUMAL, N. AND V.S.K. CHENNUBHOTLA 1997. Seaweed distribution and resources in Kerala coast. Seaweed Res. Utiln. 9 (1\&2): 29-32.

KALIMUTHU, S. 2000. Studies on some Indian members of the Rhodymeniales. Ph.D. thesis. Bharathidasan University, Tiruchirappalli, India.

MATHEW, S. S. 1991. Some Observations on the Ecology and Biochemical Aspects of the Seaweeds of Kerala Coast. Ph.D. thesis. Cochin University of Science and Technology, Kochi, India.

NAIR, B. N., V. SOBHA AND M. ARUNACHALAM 1982. Algae from southern Kerala coast.Indian J. Mar. Sci.11 (3): 266-269.

NETTAR, P.S. AND M.V.N. PANIKKAR 2009.Two new brown algal species from the family Ralfsiaceae (Ectocarpales, Phaeophyceae) from Kerala, India.Seaweed Res. Utiln. 31 (1\&2): $7-10$.

OZA, R.M. AND S.H. ZAIDI 2001. A Revised Checklist of Indian Marine Algae. CSMCRI, Bhavnagar. pp.1-296.

PANIKKAR, M.V.N. AND P. AMPILI 1993. Cloniophora capitellata Tiffany. A new record for the algal flora of Kerala. J. Econ. Taxon. Bot. 17: 460-461.

RAO, P.S.N. AND R.K. GUPTA 2015. Algae of India, Vol 3: A checklist of Indian Marine Algae (Excluding Diatoms \& Dinoflagellates). Botanical Survey of India, Kolkata, pp. 1-93.

SAUNDERS, G.W. AND B. McDONALD 2010. DNA barcoding reveals multiple overlooked Australian species of the red 
algal order Rhodymeniales (Florideophyceae), with resurrection of Halopeltis J. Agardh and description of Pseudojalopeltis gen. nov. Botany 88: 639-667.

SILVA, P.C., P.W. BASSON AND R. L. MOE 1996. Catalogue of the Benthic Marine Algae of the Indian Ocean. University of California press, London. 1259 p.

SRINIVASAN, K.S. 1965. Algarum species ex India Oriundae. Bull. Bot. Surv. India 7 (1-4): 188-266.
SRINIVASAN, K.S. 1969. Phycologia Indica (Icones of Indian Marine Algae) Vol. I. Botanical Survey of India, Calcutta.

SULEKHA, S. AND M.V.N. PANIKKAR 2006.Marine green algal flora of Kollam Coast, Kerala, South India. Seaweed Res. Utiln. 28(1): 5-21.

ALGAEBASE (http://www.algaebase.org)

WoRMS (http://www.marinespecies.org) 